\title{
THE IMPORTANCE OF SUCCESSFUL PROJECT TEAM COMMUNICATION IN AGRIBUSINESS
}

\author{
Ana Langović Milićević1, Vladimir Tomaševič ${ }^{2}$, Smiljka Isaković ${ }^{3}$
}

\begin{abstract}
Summary
Agribusiness in the Republic of Serbia is on the very beginning of its preparations for European integrations. There is a need to modernize the organizational structure, change the approach to human resources management, and introduce project approach in the realization of tasks of all businesses in this industry. Project teams are crucial for the coordination of strategic management approach and the basis for organizational strengthening and productivity growth. If project approach is not implemented properly, organizations in agribusiness will not be able to cope successfully with needed reforms. The aim of this paper is to highlight the importance of successful communication of project team members in agribusiness industry which can help to improve motivation while avoiding or minimizing misunderstandings. To analyze the problem of project team communication in agribusiness we have conducted a research on a sample of 16 project managers and 98 project staff members.
\end{abstract}

Key words: agribusiness, project team, project manager, communication, productivity.

JEL: J5, L2

\section{Introduction}

Serbian agriculture is facing many problems and difficulties in the process of adjusting to market conditions on its path towards the EU. Agriculture of Serbia and its sustainable development is in a need for agricultural policy that will stimulate the increase of productivity with help of change in the existing production structure and major investments, including clearly defined property rights and the establishment of an efficient land, credit and input

1 Ana Langović Milicević, Ph.D, Full Professor, University of Kragujevac, Faculty of Tourism and Hotel Management, Vojvođanska 5a, Vrnjacka Banja, Serbia, Phone: +381 36515 0024; E-mail: ana.langovic@kg.ac.rs

2 Vladimir Tomašević, Ph.D, Associate Professor, Alfa University, Faculty of Engineering Management, Bulevar vojvode Misica 43, Belgrade, Serbia, Phone: +381 114140 420; E-mail: vladimir.tomasevic@,fim.rs

3 Smiljka Isaković, Ph.D, Associate Professor, University of Kragujevac, Faculty of Tourism and Hotel Management, Vojvođanska 5a, Vrnjacka Banja, Serbia, Phone: +381 36515 0024; E-mail: smiljka.isakovic@,kg.ac.rs

EP 2014 (61) 2 (367-379) 
markets. Agribusiness represents the most important economic area in the Republic of Serbia, which, together with associated activities in the overall gross domestic product accounts for about 40 per cent, which indicates that Serbia is an agricultural country and for this reason it is necessary to pay special attention to agribusiness systems.

The reform process of adjusting Serbian agriculture to market conditions is facing many problems beginning from the level of development and degree of technical equipment of the food industry. Constantly present is relatively low level of capacity utilization. On the other hand, a way of organizing activities within agribusiness systems asks for a new approach to working with people and the way of their communications through project approach.

Due to changes in all aspects of business the team approach is imposed on the implementation of business tasks so that managers face now, more than ever, group activities and teamwork. Many companies can succeed only with adequate teamwork while the formation of these teams is a consequence of global expansion. Thus formed teams unite individuals with different interests which individually contribute to the activities of the team. In this way we achieve greater effectiveness because members of this team are formed in such a way that they can discuss and negotiate i.e. exchange their knowledge and diverse experiences. In addition to this advantage, the possible appearance of a conflict should be noted because of the diversity which can be cultural, geographical, organizational, functional, and so on.

In the realization of business tasks by a project approach, the manager of the team has the huge role. The main task of managers in these cases is that he or she connects all members of the group into a whole and that they strive for goals; and this is why the impact of the communication is highlighted here within the sub-processes in the organization. In fact, the manager has no hierarchical role there, but he coordinates interests. In such circumstances, the manager puts into focus the working conditions for the team, encourages cooperation among members and seeks to reconcile the differences that exist between them. To accomplish the task as a manager or team leader, with members from different cultures, he must be aware that many factors could cause misunderstanding. Culture varies in distinct, significant, and predictable ways (Adler, 2002). In order to achieve successful implementation of its role, the manager must be prepared to bear in mind in casual conversations who is the listener and what factors may be misinterpreted. One of the first prerequisites for a manager to be able to direct members adequately is to be a good listener and to prevent problems that may arise in the interaction between the project team members which may emerge due to misunderstandings in communication.

\section{Project team communication in agribusiness and European integrations}

Since the EU market for agricultural products is very demanding and selective, agricultural production must be planned and adapted to the respective needs and requirements of individual markets. Obsolescence of technology and equipment in agribusiness manufacturing industry in Serbia is an important limiting factor in the development and diversification of new products and expansion of product range. Major weaknesses are the modest marketing approach of existing producers on the EU markets, poor design and 
packing, lack of appropriate brands in exports, a large number of small exporters, as well as negligible way of managing human resources.

On the road to the EU, Serbia should develop agricultural production policies able to create brands. In order to do so, the approach to work and directing people should follow this path. Serbia has good perspective for agribusiness development and exports of agricultural products to the EU and world market. For example, in recent years, Serbian raspberries are most propulsive and profitable export product (yearly export value reached 100 million US dollars). Serbian raspberry has a label of organic food. Raspberry production is an exceptional chance for the development of agriculture and Serbian Economy in general. It could be realized through increased economic efficiency in primary productivity, as well as in the improvement in product quality (Kljajić et al., 2013). Appropriate measures of agricultural policy, primarily by stimulating the growth of productivity could significantly increase competitiveness in exports, at a time when stable import demand for these products is present on the world market.

As business systems got accustomed to operations outside of the home country, so the traditional bureaucratic structures change, and business communication is becoming more and more intercultural. However, it is unclear whether the literature on business communication also keeps up and keeps track of all the new factors affecting the communication among representatives of different cultures and cooperation during the realization of business tasks. Analysis of the results indicates that poor operating results exist due to the gap between theory and practice. Secondly, academics may have a better knowledge if the understanding of the contemporary environment is present.

The global environment imposes on companies that strategies which enable global competitiveness are set so that if they want to continue with further success they must attract, retain and develop highly educated managers and professionals. In order to provide better answers to the global environment, companies are increasingly eliminating slow, bureaucratic structures, try replace them with the new organizational structure, i.e. they implement the project approach. Contribution to this project is the focus on the increased use of technology. Via use of video teleconferencing, the project managers go now beyond national borders in managing the project team. As the implementation of business activities is expanded beyond the home country with a growing number of commercial systems and teams with members of different cultures being formed. Namely, performance of business activities increasingly brings along a project-based approach whereby the staff, that is the project team members, are to get prepared for changes to be encountered when facing a new culture (Langović Milićević and Cvetkovski, 2009). Work is becoming more integrated, employees are taught that flexibility and adaptability are desirable Changes in the environment and the project approach require a new way of communicating. It is necessary that in the near future employees improve communication skills and learn about the cultural diversity (Langović Milićević et al., 2013).

To point it out, managing project teams today is a familiar activity for the company. The factor of distance is not an aggravating factor in the performance of business activities due to 
the development of technology. A new factor that should be respected during the course of operations is: the ethnic heritage, and the attitudes and practices embedded in the culture of members of the project team that should be directed towards common goals. Individuals with the same cultural background have common modes of thought, feelings and reactions that are consistent with their cultural heritage. Behavior within task realization is consistent to cultures, and each culture has its own distinctive "style" (Hofstede, 1980). However, numerous studies show that despite the fact that there are members of different cultural heritage, it is believed that the ability of successful communication is the basis in order to achieve coordination between project team members. Of course, one should be aware that in certain cultures the explicit messages of low context are used in communication. These messages are almost " digital " and can be translated into a simple computer units (bits).

Individuals rely on formal communication when they verbally communicate information. Such low-context countries, among others, are the United States, Canada, Switzerland and Germany. In cultures of high context, the less information is transmitted verbally, as the context of communication contains much more. It is high because it includes a lot of additional information such as an individual's biography, his/her relationships, value and place in society. Thus, the message cannot be understood without its context. The high - context cultures are "the ones in which the perception of the individual is inseparably connected with his or her relationship and a context in which it appears. Such countries are Japan, China, Brazil, Mexico, Spain, Italy and the Arab nations of the Middle East (Langović Milićević et al., 2011). Studies that have attempted to compare the different behaviors in transnational project teams in different countries have mostly accepted "cultural" perspective and show that this behavior differs by culture. The impact of culture on communication is not the subject of this paper, but it is important to note that the current study can be extended to the above variables.

In the study that follows in this paper, the factor of cultural differences that may exist among the members of the project team is not analyzed, but other variables such as: active listening, solving personal problems of project team members, education, the impact of age and gender on communication, and therefore on the satisfaction or dissatisfaction which is of course reflected in their motivation during the implementation of project tasks

\section{Problem definition and hypothesis development}

The research was focused on analyzing the communication of project team members with a manager, which is a foundation for successful interaction i.e. creating the feeling of satisfaction which leads to the feeling of security, belonging and desire for proving oneself; which consequently leads to the higher motivation, which is essentially the most difficult task for every project manager. This idea was conveyed under the influence of numerous research projects, which emphasized that the communication is less successful even when the individuals with the same cultural heritage are involved, when they are cognitively different (Langović Milićević et al., 2011a). Certainly, this problem becomes more complex and this may influence the realization of project tasks if the project team consists of people with different cultural heritage. 
The research was conducted on the basis of several questions:

1. Can active listening of team members lead to the higher satisfaction of project team members?

2. Is it true that showing real interest for the associate can lead to the higher satisfaction of project team members?

3. Can creating personal relationship with associates affect communication positively?

4. Can solving employees' personal problems improve communication?

5. Is it true that managers' showing of authority can improve the communication quality?

6. Does crediting an associate with reliability improve communication?

7. Does the clear focus on tasks improve communication?

8. Does trust in the project manager and his/her capabilities affect communication positively? (This will favorably influence higher motivation and therefore the more efficient project realization will happen.)

9. To what extent is gender a relevant question within the communication context and in the project environment? (Does gender make an impact on the strategy which male and female team managers use in the communication with their members?)

The variables in these hypotheses are measured on the basis of a survey of members of the project team who have the same cultural heritage. Project teams are not identified to protect the participants, i.e. according to their desire to retain "anonymity". An attempt to capture and record the communication during the implementation of some project tasks indicates that there is a risk of anxiety and fear and all the team members who participated in the study declined this method. It has been observed that despite the promised anonymity the fear and suspicion remained which confirmed that the recording is dismissed as a way of collecting additional data.

Samples were obtained in a limited number of institutions: three companies: 16 project teams (a total of 16 project managers). The team size varied from min 5, to max 10 project team members (total of 98 members of the project teams).

The limitations of this research could be seen within the following questions:

- Is it possible to generalize the data obtained from these three companies, and in just one city?

- Do respondents answer honestly to questions?

- Does our data, which was obtained by collecting the questionnaire in a closed form, lead to the right conclusions since this method of data collection does not allow expressing the nuances of opinion or verbal expression?

In the study we used a survey technique (with structured questions, closed form of a poll for easier processing). The survey was conducted from November 2012 to February 2013.

The questionnaire, in addition to given answers, included some space for participants to write their comments and/or to provide additional information after each question. In 
this paper elective questions would have to ensure the purpose of work and proving the hypothesis. Only questionnaires which were fully completed were selected for the study.

According to the agreement with the leaders of the project team, and before the consultation, their associates were verbally informed about the project by the research assistants and asked to participate. Associates, who have agreed to participate, signed the consent form. The form was written in Serbian and English. In addition to this, the research team leader suggested that co-workers should not be required to participate for certain reason (the specifics of the project task).

It should be noted that the survey was anonymous, the respondents were members of the project team and the survey contained questions to be answered. By circling one of the answers, the respondents opted for the answer that most closely reflects their views. Since the survey was conducted according to the established rules, it can be said that the results obtained are reliable.

\section{Respondents'sample}

The major indicators of the sample structure according to the respondents' individual characteristics are the following ones:

- Respondents' gender;

- Respondents' age;

- Respondents' education level.

Table 1. Structure of respondents in a sample

\begin{tabular}{|c|c|c|c|}
\hline \multicolumn{2}{|c|}{ Structure of respondents in a sample } & Frequency & Percentage \\
\hline \multirow{3}{*}{ Project team members } & male & 75 & $77 \%$ \\
\hline & female & 23 & $23 \%$ \\
\hline & total & 98 & $100 \%$ \\
\hline \multirow{3}{*}{ Project managers } & male & 11 & $69 \%$ \\
\hline & female & 5 & $31 \%$ \\
\hline & total & 16 & $100 \%$ \\
\hline \multirow{6}{*}{$\begin{array}{l}\text { Age of respondents - members } \\
\text { in a project team }\end{array}$} & $18-24$ & 8 & $15 \%$ \\
\hline & $25-34$ & 32 & $33 \%$ \\
\hline & $35-44$ & 26 & $26 \%$ \\
\hline & $45-54$ & 29 & $30 \%$ \\
\hline & above 55 & 11 & $11 \%$ \\
\hline & total & 98 & $100 \%$ \\
\hline \multirow{6}{*}{ Age of respondents - team managers } & $18-24$ & / & 1 \\
\hline & $25-34$ & 1 & $6 \%$ \\
\hline & $35-44$ & 3 & $19 \%$ \\
\hline & $45-54$ & 12 & $75 \%$ \\
\hline & above 55 & 0 & 0 \\
\hline & total & 16 & $100 \%$ \\
\hline \multirow{4}{*}{ Education level of project team members } & high school & 25 & $26 \%$ \\
\hline & college & 20 & $20 \%$ \\
\hline & faculty & 43 & $44 \%$ \\
\hline & total & 98 & $100 \%$ \\
\hline
\end{tabular}

Source: Authors own calculation. 
The respondents' age is defined in two ways:

- Male;

- Female.

Table 2. Project managers and associates: expectations from managers

\begin{tabular}{|c|c|c|c|c|c|c|c|c|c|c|c|c|c|}
\hline \multicolumn{2}{|c|}{ Questions } & \multicolumn{11}{|c|}{ Alternatives/number and percentage of respondents according to the alternative } & \multirow[b]{2}{*}{ Response } \\
\hline 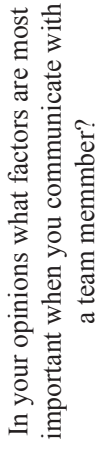 & 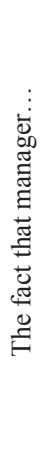 & 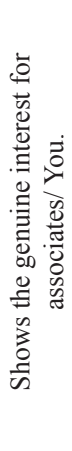 & 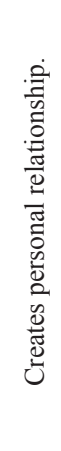 & 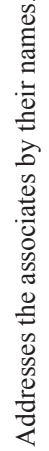 & 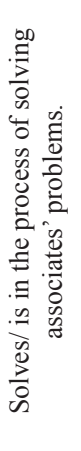 & 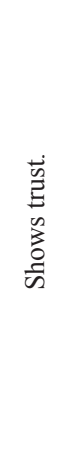 & 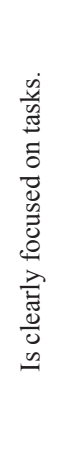 & 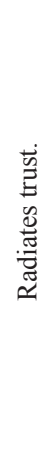 & 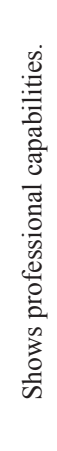 & 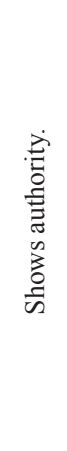 & 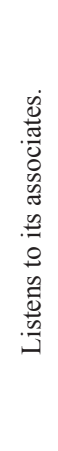 & 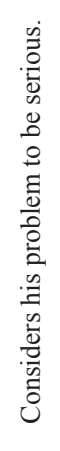 & \\
\hline \multirow{3}{*}{ 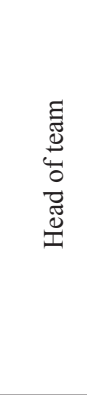 } & $\frac{\frac{\omega}{\sigma}}{\sum^{\pi}}$ & $\begin{array}{c}0 \\
0 \%\end{array}$ & $\begin{array}{c}0 \\
0 \%\end{array}$ & $\begin{array}{c}1 \\
9 \%\end{array}$ & $\begin{array}{c}0 \\
0 \%\end{array}$ & $\begin{array}{c}1 \\
9 \%\end{array}$ & $\begin{array}{c}5 \\
46 \%\end{array}$ & $\begin{array}{c}0 \\
0 \%\end{array}$ & $\begin{array}{c}0 \\
0 \%\end{array}$ & $\begin{array}{c}2 \\
18 \%\end{array}$ & $\begin{array}{c}2 \\
18 \%\end{array}$ & $\begin{array}{c}0 \\
0 \%\end{array}$ & 11 \\
\hline & 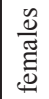 & $\begin{array}{c}0 \\
0 \%\end{array}$ & $\begin{array}{c}1 \\
20 \%\end{array}$ & $\begin{array}{c}0 \\
0 \%\end{array}$ & $\begin{array}{c}0 \\
0 \%\end{array}$ & $\begin{array}{c}0 \\
0 \%\end{array}$ & $\begin{array}{c}0 \\
0 \%\end{array}$ & $\begin{array}{c}0 \\
0 \%\end{array}$ & $\begin{array}{c}0 \\
0 \%\end{array}$ & $\begin{array}{c}0 \\
0 \%\end{array}$ & $\begin{array}{c}3 \\
60 \%\end{array}$ & $\begin{array}{c}1 \\
20 \%\end{array}$ & 5 \\
\hline & \multicolumn{12}{|c|}{ Total } & 16 \\
\hline \multirow{3}{*}{ 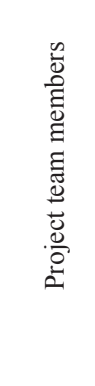 } & $\frac{0}{\frac{0}{\pi}}$ & $\begin{array}{c}2 \\
3 \%\end{array}$ & $\begin{array}{c}3 \\
4 \%\end{array}$ & $\begin{array}{c}4 \\
5 \%\end{array}$ & $\begin{array}{c}5 \\
6 \%\end{array}$ & $\begin{array}{c}1 \\
1 \%\end{array}$ & $\begin{array}{c}17 \\
23 \%\end{array}$ & $\begin{array}{c}3 \\
4 \%\end{array}$ & $\begin{array}{c}2 \\
3 \%\end{array}$ & $\begin{array}{c}15 \\
20 \%\end{array}$ & $\begin{array}{c}21 \\
28 \%\end{array}$ & $\begin{array}{c}2 \\
3 \%\end{array}$ & 75 \\
\hline & 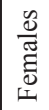 & $\begin{array}{c}1 \\
4 \%\end{array}$ & $\begin{array}{c}3 \\
13 \%\end{array}$ & $\begin{array}{c}1 \\
4 \%\end{array}$ & $\begin{array}{c}3 \\
13 \%\end{array}$ & $\begin{array}{r}0 \\
0 \%\end{array}$ & $\begin{array}{c}0 \\
0 \%\end{array}$ & $\begin{array}{c}0 \\
0 \%\end{array}$ & $\begin{array}{c}0 \\
0 \%\end{array}$ & $\begin{array}{c}0 \\
0 \%\end{array}$ & $\begin{array}{c}13 \\
57 \%\end{array}$ & $\begin{array}{c}2 \\
9 \%\end{array}$ & 23 \\
\hline & \multicolumn{12}{|c|}{ Total } & 98 \\
\hline
\end{tabular}

Source: Authors own calculation

According to the analysis of the survey it was observed that the highest percentage of male managers considered that the basis of good communication is in directing employees to the task (46\%), followed by emphasis of the authority (18\%) and actively listening to associates $(18 \%)$. 
Women project managers preferred active listening to associates $(60 \%)$, creating personal relationships with members of the project team as well as a serious understanding of their problems.

Male members of the project team believe that the major criteria for successful communication in relation to others is that the team leaders actively listen to colleagues $(28 \%)$, then it is essential that they direct assignments $(23 \%)$ and emphasize their authority $(20 \%)$. The analysis of the survey indicated that what is essential for members of the project team is managers' readiness to assist in solving personal problems and addressing by name, but project managers (male) did not declare that these items may be the causes of misunderstanding.

Female members of the project team listed in the first place as the most important criteria for effective communication that the project manager actively listens to them (57\%), understands their problems seriously, and as women project managers also pointed out, the project manager knows how to create personal relationships and is willing to solve their personal problem. According to them, it is least important that project managers call them by their first name.

Table 3. Reasons for the lack of satisfaction in the communication with team managers

\begin{tabular}{|c|c|c|c|c|c|c|}
\hline \multicolumn{2}{|c|}{ Questions } & \multicolumn{4}{|c|}{$\begin{array}{l}\text { Alternatives/number and } \% \text { of respondents } \\
\text { according to alternatives }\end{array}$} & \multirow[b]{2}{*}{ Responses } \\
\hline \multicolumn{2}{|c|}{$\begin{array}{c}\text { If the answer is less satisfactory/ } \\
\text { unsatisfactory... }\end{array}$} & 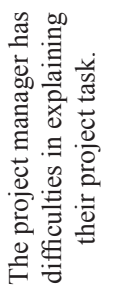 & 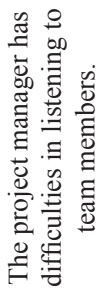 & 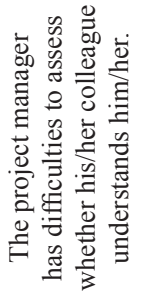 & $\begin{array}{l}\overrightarrow{\omega_{0}} \\
\stackrel{0}{0} \\
\stackrel{g}{E}\end{array}$ & \\
\hline \multirow{3}{*}{ Team member } & Male & $\begin{array}{c}14 \\
19 \%\end{array}$ & $\begin{array}{c}35 \\
47 \%\end{array}$ & $\begin{array}{c}15 \\
20 \%\end{array}$ & $\begin{array}{c}11 \\
14 \%\end{array}$ & 75 \\
\hline & Female & $\begin{array}{c}4 \\
17 \%\end{array}$ & $\begin{array}{c}11 \\
48 \%\end{array}$ & $\begin{array}{c}6 \\
26 \% \\
\end{array}$ & $\begin{array}{c}2 \\
9 \% \\
\end{array}$ & 23 \\
\hline & \multicolumn{5}{|c|}{ Total } & 98 \\
\hline
\end{tabular}

Source: Authors own calculation

The reasons for the lack of satisfaction of male members in project teams are the following ones: when the manager is not willing to listen to them (47\%), which indicates that this factor is very important in the process of communication (Table 3), then the project managers' inability to realize how his instructions are accepted i.e. whether his/ her associate understands him and is able to explain the project task. Employee satisfaction directly or indirectly affects their behavior and more satisfied workers are less likely to leave their employer (Kovačević et al., 2012).

The reasons for the lack of satisfaction among female members in a project team are the same as for their male associates, i.e. the managers' unwillingness to listen to the member of the project team $(48 \%)$, project managers' difficulties to realize whether his associates 
understand him/her and then at the third place the difficulty of project manager in explaining the project task.

Table 4. Answers of the project managers

\begin{tabular}{|c|c|c|c|c|c|}
\hline \multirow{2}{*}{$\begin{array}{l}\quad \text { Questions } \\
\text { Is there a } \\
\text { misunderstanding in } \\
\text { communication }\end{array}$} & \multicolumn{4}{|c|}{$\begin{array}{l}\text { Alternatives /number \% of respondents according to } \\
\text { alternatives }\end{array}$} & \multirow[b]{2}{*}{ Responses } \\
\hline & Yes, often & Yes, sometimes & Seldom & No, never & \\
\hline Male manager & $\begin{array}{c}2 \\
18 \% \\
\end{array}$ & $\begin{array}{c}7 \\
64 \% \\
\end{array}$ & $\begin{array}{c}2 \\
18 \% \\
\end{array}$ & $\begin{array}{c}0 \\
0 \% \\
\end{array}$ & 11 \\
\hline Female manager & $\begin{array}{c}0 \\
0 \% \\
\end{array}$ & $\begin{array}{c}0 \\
0 \% \\
\end{array}$ & $\begin{array}{c}4 \\
80 \% \\
\end{array}$ & $\begin{array}{c}1 \\
20 \% \\
\end{array}$ & 5 \\
\hline
\end{tabular}

Source: Authors own calculation

On the other hand, when asked whether the misunderstanding in the communication with project team members exists, male project managers indicated that this happens occasionally (64\%). Interestingly, there was no a single project manager with a situation that they never at all faced the misunderstanding. On the other hand, we can indicate the link with the previous table (Table 4) the project managers have difficulties to realize whether their associate understood them well, which can be also a reason for misinterpretation.

Female project managers indicated that they rarely experience misunderstanding in the communication (even $80 \%$ of them), and even $20 \%$ circled "no, never" as their answers. A slight misunderstanding in the communication problems was probably caused by the fact that it is important to listen to a female project manager to listen to her associates and team members of both genders.

Table 5. Project manager: satisfaction level in communication

\begin{tabular}{|c|c|c|c|c|c|c|c|}
\hline Questions & \multicolumn{6}{|c|}{ Alternatives /number \% of respondents according to alternatives } & \multirow{3}{*}{ 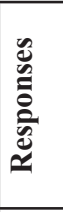 } \\
\hline $\begin{array}{c}\text { What is your } \\
\text { experience in the }\end{array}$ & $\begin{array}{c}\text { Male } \\
\text { manager }\end{array}$ & $\begin{array}{c}\text { Female } \\
\text { manager }\end{array}$ & $\begin{array}{c}\text { Male } \\
\text { manager }\end{array}$ & $\begin{array}{c}\text { Female } \\
\text { manager }\end{array}$ & $\begin{array}{c}\text { Male } \\
\text { manager }\end{array}$ & $\begin{array}{c}\text { Female } \\
\text { manager }\end{array}$ & \\
\hline $\begin{array}{l}\text { communication } \\
\text { with managers? }\end{array}$ & \multicolumn{2}{|c|}{ Very satisfactory } & \multicolumn{2}{|c|}{ Satisfactory } & \multicolumn{2}{|c|}{ Unsatisfactory } & \\
\hline $\begin{array}{l}\text { Male members in a } \\
\text { project team }\end{array}$ & $\begin{array}{c}22 \\
29 \%\end{array}$ & $\begin{array}{c}38 \\
51 \%\end{array}$ & $\begin{array}{c}6 \\
8 \%\end{array}$ & $\begin{array}{c}8 \\
11 \%\end{array}$ & $\begin{array}{c}1 \\
1 \%\end{array}$ & $\begin{array}{c}0 \\
0 \%\end{array}$ & 75 \\
\hline $\begin{array}{l}\text { Female members } \\
\text { in a project team }\end{array}$ & $\begin{array}{c}5 \\
22 \% \\
\end{array}$ & $\begin{array}{c}11 \\
48 \% \\
\end{array}$ & $\begin{array}{c}3 \\
13 \% \\
\end{array}$ & $\begin{array}{c}4 \\
17 \\
\end{array}$ & I & / & 23 \\
\hline
\end{tabular}

Source: Authors own calculation

For the male members of the project team it was noted that a large percentage is very satisfied in the communication with their managers, but more with female than male project managers.

Women members of the project team did not feel dissatisfaction in the communication with either male or female project managers. They rated the level of the communication with their project manager very highly, which was again in favor of female project managers. 
It was found that women managers spend more time than men who lead the project team in the consultation with their partners and that they actively facilitate the participation of their associates as they attempt to equalize the status by taking a less dominant position in the relationship. In addition, consultations with women leaders are acknowledged more like a positive conversation, counseling, than consulting with male managers. Non-verbal behavior is different, it provides more feedback than the consultation with male counterparts. In contrast, male project managers tend to "impose more authority" (to give advice and to paraphrase more - which was added in the questionnaires at a place for comments) and male managers are also more verbally dominant while female managers and associates are attentive listeners. Similarly, this study showed that male managers have little quantitative dominance in the interaction (i.e. they produce more words in a conversation with their co-workers than women and have a tendency to dominate the interaction more than their female colleagues).

As far as the associates' gender is concerned, the research shows that female associates show greater participation in interactions with managers, especially with the leaders - women (i.e. in female - female consultations), co-workers tend to seek a partnership with women rather than with male co-workers. Women tend more to seek relationships and to have affective reactions to events, while men often give objective reports of events. Female associates are given longer deadlines from their managers and more instructions during the implementation of project tasks, and they show that female associates are more diffuse in the presentation of business problems, while the lack of time is a common problem of managers involved in consultations with female co-workers than among men. They also point out that female associates talk about feelings at a higher rate than male associates.

Female-female consultations are longer than male-male consultations, which are also shorter than combinations of diverse genders; female-female consultations are also more egalitarian, that is, the manager and assistant contribute equally to the dialogue and this shows that female-female consultations are more psycho-socially oriented in relation to other combinations of genders.

As far as the behavior of inquiring is concerned, it is not surprising that women managers ask more questions about social problems of their associates, however, there is no clear tendency of a question concerning the format (i.e. the type of question) and whether the question of male and female managers and male and female associates (which is added to the survey on the place for comments). Interestingly, longer female-female consultations include more social discussion and the emotional conversation.

Male managers tend to ask approximately the same number of questions to the male and female co-workers, and women leaders ask more women associates than male ones. In addition, male associates ask more questions to women leaders than men. In this study it was observed that the male and female communicative styles are different, and it has an impact on the interaction during the implementation of project tasks. However, one should not forget that gender is the only one of many factors that may correlate with the behavior, beliefs, and perceptions. Therefore, researchers should not focus on gender in isolation from other personal (e.g. age, ethnicity, nationality), and situational attributes that also influence 
the interaction. Gender is biological, but at the same time it can be seen within the social and cultural aspects which require the special study.

Communication with staff managers is also closely associated with their age, the older associates accept more easily the traditional asymmetry in the relationship manager - assistant than younger ones and tend to be less involved in decision-making (based on comments on the questionnaire). Generation differences in symbols, heroes, rituals, and values are evident to most people. They are often overestimated. Many differences in practice and values between generations are normal attributes of age that repeat themselves for each successive pair of generations (Hofstede and Hofstede, 2005). The level of education and care are also factors, for example, where more educated worker will ask more questions and offer more opinions to his supervisor. Here, one should not lose the sight of the type of project tasks which also affects communication. Research shows differences related to associates and their educational status in terms of communication; communication with co-workers where the secondary education is characterized by, among other things, providing less information, fewer instructions and less frequent socio-emotional communication (added in a separate questionnaire for comments). Racial differences may also play a role and influence the exchange of information during consultations, but here this was not a subject of research

\section{Conclusion}

Agribusiness in Serbia is at the very beginning of preparations for European integrations. Modernization of agriculture, changes in the approach to human resource management and introduction of project approach to all business entities in the industry is required. Particular attention should be paid to increasing productivity through project management.

The world today is a global community which experiences quick and grave changes which influence huge challenges and temptations. The reason for change and the factors which create the very changes were closely connected since time immemorial with a problem of management model. In the contemporary business conditions, this interconnectedness especially stands out.

These changes in the global environment require that a new manager is ready for operation and that he/she has a new approach to managing projects with members of different cultural environments. This has led to a number of educational efforts, through training and development organization, where diversity is better managed in the workplace and in the provision of services. Therefore, when communication between the managers of the project team and associates are not correlated with their present dissatisfaction, the motivation decreases and hence project results are poor. This paper argues that one of the first approaches in order to successfully communicate with associates of the project team is to be an active listener. Research shows that members of the project team put higher prices when they hear the manager or provide assistance in solving a personal problem. Although creative forms of motivation, in this case, active listening of associates, solving personal problems require greater involvement 
of managers, in the end they bring many benefits. It is important to workers that their involvement contributes substantially to a successful business, as well as that those managers recognize that and are interested in the personal circumstances of each. Therefore, it is important to re- emphasize that open and direct communication between the manager and the project team members, which is one of the key motivating factors.

Factors contributing to worse communication are often associated with organizational constraints and conditions under which managers operate. These include the lack of time, the pressure of work and various harassment and cultural diversity. Cultural differences between managers and their staff can also affect the performance of communication and later end results. It is important to point out that the education system must also follow this development. In this world the training of workers is already present in terms of communication through continuing education regardless of the activity they are engaged in.

Therefore, the effects of communication can improve education at the undergraduate level, i.e. including the development of skills to interact regardless of the faculty field which is as important for every individual regardless of the activity they are engaged in. One suggestion arising from this study is that the ability to competently communicate with associates in a project team becomes a prerequisite for obtaining the project manager license.

\section{Literature}

1. Adler, N. J. (2002): International dimensions of organizational behavior, ch.no. I, Wadsworth, Belmont, p. 35.

2. Hofstede, G., Hofstede, G. J. (2005): Cultures and organizations. Software of the mind, McGraw-Hill, New York.

3. Hofstede, G. (1980): Culture's consequences. International differences in work-related values, Sage Publications, London.

4. Kljajić, N., Vuković, P., Arsić, S. (2013): Tendencies related to the production of raspberries in the republic of Serbia, Economics of Agriculture, Institute of Agricultural Economics, Belgrade, Serbia, Vol. 60, No. 1, p. 46.

5. Kovačević, B., Gajić, T., Penić, M. (2012): Job satisfaction among the employees in Novi Sad's tourist agencies, Economics of Agriculture, Institute of Agricultural Economics, Belgrade, Serbia, Vol. 59, No. 2, pp. 217-228.

6. Langović Milićević, A. Cvetkovski, T. Langovic, Z. (2011):Negotiation and Globalization, International Journal of Engineering, Vol. 9 Issue 3, p131 -136, Faculty Engineering Hunedoara, Huneduara, Romania

7. Langović Milićević, A., Cvetkovski, T. (2009): Realization of Business Activities in Respect of Cultural Factors, $2^{\text {nd }}$ International Conference Entrepreneurship, Innovation and Regional Development, ICEIRD 2009, Thessaloniki, Greece, pp. 367-376.

8. Langović Milićević, A., Cvetkovski, T., Langović, Z. (2011a): Globalization and 
Multiculturalism - Business Systems Development in Southern Banat, International Scientific Conference" Strengthening the Competitiveness and Economy Bonding of Historical Banat - SCEBB", Vrsac, Serbia, pp. 157-164.

9. Langović Milićević, A., Cvetkovski, T., Langović,Z. (2013): Menadžment i obrazovanje u uslovima globalizacije, HiT Menadžment, Vol. 1, no. 1, p. 69.

\title{
ZNAČAJ USPEŠNE KOMUNIKACIJE PROJEKTNOG TIMA U AGROBIZNISU
}

\author{
Ana Langović Milićevič ${ }^{4}$, Vladimir Tomaševič́, Smiljka Isakovićc
}

\section{Rezime}

Agrobiznis u Republici Srbiji je na samom početku priprema za evropske integracije. Postoji potreba modernizacije organizacione strukture, promene pristupa ljudskim resursima $i$ uvođenja projektnog pristupa u realizaciji zadataka svih privrednih subjekata u ovoj delatnosti. Projektni timovi su od krucijalnog značaja za koordinaciju prsitupa strateškom upravljanju i osnova su za organizaciono jačanje i rast produktivnosti. Ako se projektni pristup ne primeni na odgovarajući način, organizacije u agrobiznisu neče biti u stanju da se uspešno nose sa neophodnim reformama. Cilj ovog rada je da ukaže na značaj uspešne komunikacije članova projektnih timova u agrobiznisu koja može da poboljša motivaciju $i$ da istovremeno utiče na izbegavanje ili minimiziranje nerazumevanja. Da bismo analizirali problem komnikacije projektnih timoviau agrobiznisu, uradili smo istraživanje na uzorku 16 projektnih menadžera i 98 projektnih saradnika.

Ključne reči: agribiznis, projektni tim, projektni menadžer, komunikacija, produktivnost.

4 Dr Ana Langović Milicević, Redovni profesor, Univerzitet u Kragujevcu, Fakultet za turizam i hotelijerstvo, Vojvođanska 5a, Vrnjacka Banja, Srbija, Telefon: +381 36515 0024; E-mail: ana.langovic@kg.ac.rs

5 Dr Vladimir Tomašević, Vanredni profesor, Alfa univerzitet, Fakultet za inzenjerski menadzment, Bulevar vojvode Misica 43, Beograd, Srbija, Telefon: +381 114140 420; E-mail: vladimir.tomasevic@,fim.rs

6 Dr Smiljka Isaković, Vanredni profesor, Univerzitet u Kragujevcu, Fakultet za turizam i hotelijerstvo, Vojvođanska 5a, Vrnjacka Banja, Srbija, Telefon: +381 36515 0024; E-mail: smiljka.isakovic@,kg.ac.rs

EP 2014 (61) 2 (367-379) 